\title{
Relationship between Renal Failure and Hypertension among Patients in Riyadh, Saudi Arabia
}

\author{
Ahmed Abdulrahman Aldhahi ${ }^{1 *}$, Hassan Ramzi Al-Suliman ${ }^{2}$, Abdulaziz Abdullah S. Al Nahdi ${ }^{3}$ \\ Abdulrahman Abdulwahab Asiri ${ }^{4}$, Ibrahim Nasser Asiri ${ }^{4}$, Abdullah Mohammed Khudhayri ${ }^{4}$, \\ Mohammed Ahmed Asiri ${ }^{4}$ \\ ${ }^{1}$ Imam Muhammad Ibn Saud Islamic University, Riyadh, ${ }^{2}$ King Fahad Hospital, Al-Hofuf, ${ }^{3}$ \\ University of Jeddah, ${ }^{4}$ King Khalid University, Abha, Saudi Arabia \\ *Corresponding Author: Ahmed Abdulrahman Aldhahi, E-mail; Aldhahi_93@hotmail.com
}

\begin{abstract}
Background: chronic kidney disease (CKD) is common in Saudi although there are few data on the prevalence of this disorder. Therefore, we initiated a multicenter screening study to identify the prevalence and staging of CKD in 712 patients with known hypertension in four hospitals in Riyadh, Saudi Arabia.

Method: we measured estimated glomerular filtration rate by the six-variable modification of diet in renal disease equation and proteinuria by the protein/creatinine ratio. All the subjects studied were Saudis.

Results: of the 712 patients studied, the median age was 59 years (range 19-90 years) and 560 (78.7\%) of the patients were female. The mean duration of hypertension was 4 years (range 0.1-50). The overall prevalence of CKD was 46.9\% (95\% CI: 43.2-50.7\%); $19.1 \%$ had CKD stages 1-2 and $27.8 \%$ had CKD stages 3-5. There was no difference in age between patients with or without CKD (p $=0.12$ ). The overall prevalence of proteinuria was $28.9 \%$ (95\% CI: $25.6-32.4 \%$ ); $14.7 \%$ of subjects had preexisting diabetes mellitus and their prevalence of CKD (55\%; 95\% CI: 42.4-62.2) did not differ from those without diabetes $(46 \%$; $95 \%$ CI: 41.9-50.0, $p=0.133)$

Conclusion: CKD is common in hypertensive patients in Riyadh, Saudi Arabia with a prevalence of 46.9\%. This provided justification for the inclusion of this group in CKD screening programs in Saudi.
\end{abstract}

Keywords: Hypertension; chronic kidney disease; Riyadh

\section{INTRODUCTION}

In studies published in the United States, Europe, Asia, and Australia, it was found that chronic kidney disease (CKD) affects between $5 \%$ and $15 \%$ of the adult population ${ }^{(1-4)}$, making this a major public health problem ${ }^{(5)}$. The more severe stages of CKD (3-5) are a major risk factor for cardiovascular disease as well as for more severe renal failure (CKD stages 4 and 5) ${ }^{(6)}$. Although CKD is common in Saudi, there are few data on prevalence and little is known about progression in patients with this disease. Previous studies from Saudi showed a prevalence of CKD of $10.4 \% 7$ and proteinuria of $12.4 \%{ }^{(8)}$. Hypertension is recognized as an important cause of CKD. In a study carried out in Ghana, of 365 outpatients with hypertension, 110 (30.2\%) had serum creatinine $>140 \mu \mathrm{mol} / \mathrm{L}(1.6 \mathrm{mg} / \mathrm{dL}), 48$ had serum creatinine $>400 \mu \mathrm{mol} / \mathrm{L}(>4.5 \mathrm{mg} / \mathrm{dL})$, and $96(25.5 \%)$ had proteinuria ${ }^{(9)}$. In another study from Burkina Faso, 117 out of 317 (44\%) patients were with hypertension were hospitalized had chronic renal failure ${ }^{(10)}$. In an autopsy study, we showed that hypertension was an important cause of end-stage renal failure in Saudi, accounting for 33 out 78 $(42 \%)$ cases ${ }^{(11)}$. This apparent high prevalence of CKD in patients with hypertension is important for one reason. First, hypertension is common in many parts of Saudi with prevalence in adults in Riyadh of over $28 \%^{(13,14)}$. For this reason, a study of the prevalence of CKD in patients with hypertension and the institution of measures to slow its progression is of great importance in these areas.

\section{MATERIALS AND METHODS}

This study was a prospective cross-sectional survey of hypertensive patients aged over 16 attending four hospitals in Riyadh, Saudi Arabia. The subjects enrolled in this study were all being followed up for hypertension and were on treatment. After obtaining 
informed consent, demographic data were obtained using a questionnaire.

The blood pressure was recorded after a $5 \mathrm{~min}$ rest using a mercury sphygmomanometer with a standard or a large cuff. Serum creatinine was determined using the Jaffe reaction in continuous flow on an ATAC 8000 automated chemistry analyzer. Urine creatinine concentration was measured using rate alkaline picrate methods with the ATAC 8000 automated chemistry analyzer. The protein in the urine was precipitated with trichloroacetic acid and redissolved in alkali. The urine protein was measured colorimetrically using the Biuret reaction. The urine protein/creatinine ratio (PCR) was reported as $\mathrm{mg} / \mathrm{mg}$. Proteinuria was defined as a PCR greater than 0.3 in women and 0.2 in men. The estimated glomerular filtration rate (eGFR) was calculated using the modification of diet in renal disease (MDRD) six-variable prediction equation ${ }^{(15)}$ as follows: eGFR = $170 *(\mathrm{scr})-0.999 \AA \sim$ (age) $-0.176 \AA$ (bun) $0.176 \AA \sim$ (alb) $+0.318 \AA \sim 0.762$ (if female) $\AA \sim$ 1.178. Estimated GFR is reported as $\mathrm{mL} / \mathrm{min} / 1.73 \mathrm{~m} 2$. The CKD stages were defined using the kidney disease outcomes quality initiative classification ${ }^{(16)}$.

All patients gave written informed consent.

\section{Statistical Analysis:}

All analyses were performed using StataCorp 2007 (Stata Statistical Software: Release 10, StataCorp LP, and College Station, TX, USA). Continuous variables were summarized by their means and standard deviations or median and range and categorical variables as percentages. Differences in normally distributed continuous variables were compared using Student's t -test, in nonnormally distributed data by the MannWhitney $U$ test or the Kruskal-Wallis equality-of-populations rank test, and in proportions by the $x^{2}$ test.

\section{RESULTS}

Demographic and Baseline Laboratory Data of the 712 participating patients, that were 152 males $(21.3 \%)$ and $560(78.7 \%)$ females are shown in Table 1. The median (range) age of the patients was 59 years (19-90) years and the median (range) body mass index (BMI) was 29.7 (12.2-67.4). The median systolic blood pressure was $150 \mathrm{mmHg}(100-280)$ and the median diastolic blood pressure was $90 \mathrm{mmHg}$ $(60$ - 160). The median duration of hypertension was 4 years (0.1-50.0). The median number of hypertensive drugs used was $2(0-5)$, with $179(25.1 \%)$ of the patients taking angiotensin-converting enzyme inhibitors or angiotensin receptor blockers. Other drugs taken were calcium channel blockers by $592(83.1 \%)$, beta-blockers by 255 (35.8\%), and diuretics by $394(55.3 \%)$ of the subjects. Using the kidney disease outcomes quality initiative staging of $\mathrm{CKD}$, the overall prevalence of CKD was $46.9 \%$ (95\% CI: 43.250.7). The percentage of subjects with an eGFR $\geq 60 \mathrm{~mL} / \mathrm{min} / 1.73 \mathrm{~m}^{2}$ with proteinuria (CKD stages 1-2) was $19.1 \%$ and with an eGFR of $<60 \mathrm{~mL} / \mathrm{min} / 1.73 \mathrm{~m}^{2}$ (CKD stages 35) was $27.8 \%$. The prevalence of proteinuria was $28.9 \%$ (95\% CI: 25.6-32.4). There was no difference in age between patients with CKD $(57 ; 27-89)$ and without CKD $(59 ; 19-90), \mathrm{p}=$ 0.12 .

One hundred and five patients had diabetes mellitus $(14.7 \%)$ and their data are compared with patients without diabetes in Table 1 . There was no significant difference in the prevalence of CKD in patients with diabetes (52.4\%; 95\% CI: 42.4-62.2) as compared with patients without diabetes $(46.0 \%$; 95\% CI: 41.9 - 50.0), $\mathrm{p}=0.133$. Cardiovascular disease, mostly cerebrovascular accidents were found in $4.9 \%$ of the patients. This did not differ between patients with diabetes or without diabetes $(\mathrm{p}=0.392)$. Patients with diabetes were more likely to have a higher BMI than patients without $\left(x^{2}=8.1 ; \mathrm{p}=\right.$ $0.02)$, and they had a higher urine PCR $0.2(0-$ 11.8) compared with $0.1(0.1-17.1), \mathrm{p}=0.001$. Patients with diabetes were more likely to be treated with angiotensin blockade $61.5 \%$ versus $19.6 \%(\mathrm{p}<0.001)$ and had lower hemoglobin $(\mathrm{p}=0.026)$. There was no difference in systolic or diastolic pressure between patients with diabetes and those without diabetes. Patients with the more advanced stages of CKD were younger than patients with the earlier stages ( $p=0.0001)$ as shown in Table 2. Patients with

CKD1, 2, and 4 had higher levels of proteinuria compared to patients with CKD 3 and 5. Although CKD occurred more frequently in older patients, the difference was not significant ( $x^{2}$ for trend, $\mathrm{p}=0.901$ ), (Table 2). Cardiovascular events were few and did not correlate with the severity of CKD. 
Table 1. Demographic and clinical characteristics of participants

\begin{tabular}{|c|c|c|c|c|}
\hline Variable & Cohort $(\mathrm{n}=712)$ & $\begin{array}{l}\text { Diabetes }(\mathrm{n}= \\
105)\end{array}$ & $\begin{array}{l}\text { No diabetes }(\mathrm{n}= \\
607)\end{array}$ & 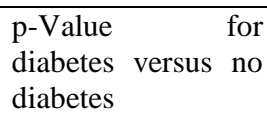 \\
\hline $\begin{array}{l}\text { Age, year [median } \\
\text { (range)] }\end{array}$ & $59(19-90)$ & $60(34-84)$ & $58(19-90)$ & 0.049 \\
\hline \multicolumn{5}{|l|}{ Gender [n (\%)] } \\
\hline Male & $152(21.3)$ & $20(19.0)$ & $132(21.7)$ & \\
\hline Female & $560(78.7)$ & $85(81.0)$ & $475(78.3)$ & \\
\hline \multicolumn{5}{|l|}{$\begin{array}{l}\text { Medical history [n } \\
(\%)]\end{array}$} \\
\hline $\begin{array}{l}\text { MI or ischemic heart } \\
\text { disease }\end{array}$ & $2(0.3)$ & $0(0.0)$ & $2(0.3)$ & \\
\hline Chronic heart failure & $3(0.4)$ & $0(0.0)$ & $3(0.5)$ & \\
\hline CVA & $30(4.2)$ & $4(3.8)$ & $26(4.3)$ & \\
\hline Total & $35(4.9)$ & $4(3.8)$ & $31(5.1)$ & 0.392 \\
\hline \multicolumn{5}{|l|}{$\mathrm{BP}$ variables } \\
\hline $\begin{array}{l}\text { Systolic BP, mmHg } \\
\text { [median(range)] }\end{array}$ & $150(100-280)$ & $150(110-230)$ & $150(100-280)$ & 0.815 \\
\hline $\begin{array}{l}\text { Diastolic BP, } \mathrm{mmHg} \\
\text { [median(range)] }\end{array}$ & $90(60-160)$ & $90(60-140)$ & $90(60-160)$ & 0.094 \\
\hline $\begin{array}{l}\text { Median duration of } \\
\text { hypertension, year } \\
\text { [median (range)] }\end{array}$ & $4(0.1-50)$ & $4(0.25-50)$ & $4(0.1-50)$ & 0.476 \\
\hline $\begin{array}{l}\mathrm{BP}>130 / 80 \quad \mathrm{mmHg} \\
{[\mathrm{n}(\%)]}\end{array}$ & $478(67.1)$ & $62(59.0)$ & $416(68.5)$ & 0.04 \\
\hline $\begin{array}{l}\text { Weight, kg [median } \\
\text { (range)] }\end{array}$ & $75(34-155)$ & $79.4(48.6-124.0)$ & $75(34-155)$ & 0.129 \\
\hline $\begin{array}{l}\text { BMI, kg/m2 [median } \\
\text { (range)] }\end{array}$ & $29.7(12.2-67.4)$ & $30.8(19.4-50.0)$ & $29.4(12.2-67.4)$ & 0.07 \\
\hline BMI, kg/m2 [n (\%)] & & & & $\begin{array}{l}x^{2}=8.1 \\
p=0.02\end{array}$ \\
\hline$<25.0$ & $159(22.3)$ & $12(11.4)$ & $147(24.2)$ & \\
\hline $25.0-29.9$ & $185(26.0)$ & $31(29.5)$ & $154(25.4)$ & \\
\hline$>30.0$ & $326(45.7)$ & $54(51.4)$ & $272(44.8)$ & \\
\hline $\begin{array}{l}\text { eGFR, } \mathrm{mL} / \mathrm{min} / 1.73 \\
\mathrm{~m} 2 \text { [median(range)] }\end{array}$ & $73.0(1.68-209.5)$ & $76.6(4.6-209.5)$ & $72.1(1.68-204.1)$ & 0.875 \\
\hline \multicolumn{5}{|l|}{ CKD stages [n (\%)] } \\
\hline CKD1 & $62(8.7)$ & $10(9.5)$ & $52(8.6)$ & \\
\hline CKD2 & $74(10.4)$ & $11(10.5)$ & $63(10.4)$ & \\
\hline CKD3 & $169(23.7)$ & $29(27.6)$ & $140(23.1)$ & \\
\hline CKD4 & $22(3.1)$ & $4(3.8)$ & $18(3.0)$ & \\
\hline CKD5 & $7(1.0)$ & $1(1.0)$ & $6(1.0)$ & \\
\hline Total CKD [n (\%)] & $\begin{array}{l}334(46.9 ; 95 \% \\
\text { CI: 43.2-50.7) } \\
\end{array}$ & $\begin{array}{l}55(52.4 ; 95 \% \\
\text { CI: 42.4-62.2) }\end{array}$ & $\begin{array}{l}279(46.0 ; 95 \% \\
\text { CI: 41.9-50.0) }\end{array}$ & 0.133 \\
\hline $\begin{array}{l}\text { Urine } \\
\text { protein/creatinine } \\
\text { ratio, } \mathrm{mg} / \mathrm{mg} \\
{[\text { median (range)] }}\end{array}$ & $0.1(0-17.1)$ & $0.2(0-11.8)$ & $0.1(0-17.1)$ & 0.001 \\
\hline $\begin{array}{lr}\text { Number } & \text { of } \\
\text { hypertensive } & \text { drugs } \\
\text { [median } & \\
\text { (range)] } & \\
\end{array}$ & $2(0-5)$ & $2(0-4)$ & $2(0-5)$ & 0.51 \\
\hline $\begin{array}{l}\text { ACEI or ARB } \\
\text { therapy }[\mathrm{n}(\%)]\end{array}$ & 179 & $64(61.0)$ & $115(18.9)$ & $<0.001$ \\
\hline $\begin{array}{l}\text { Hemoglobin, g/dL } \\
\text { [median (range)] }\end{array}$ & $13.5(7.3-18.0)$ & $13.3(8.4-16.2)$ & $13.7(7.3-18.0)$ & 0.026 \\
\hline
\end{tabular}

Note: MI, myocardial infarction; CVA, cerebrovascular accident; ACEI, angiotensin converting enzyme inhibitors; $\mathrm{ARB}$, angiotensin receptor blockers. 
Table 2. Characteristics of patients by CKD stage

\begin{tabular}{|c|c|c|c|c|c|c|c|}
\hline \multirow[t]{2}{*}{ Variable } & \multicolumn{4}{|c|}{ CKD stages } & & & \multirow[t]{2}{*}{ p-Value } \\
\hline & CKD1 & CKD2 & CKD3 & CKD4 & CKD5 & $\begin{array}{l}\text { Total } \\
\text { CKD }\end{array}$ & \\
\hline $\mathrm{n}$ & 62 & 74 & 169 & 22 & 7 & 334 & \\
\hline $\begin{array}{l}\text { Age, year } \\
\text { [median (range)] }\end{array}$ & $\begin{array}{l}55.0 \\
(19-83)\end{array}$ & $\begin{array}{l}59.5 \\
(34-87)\end{array}$ & $\begin{array}{l}61.0 \\
(28-90)\end{array}$ & $50.0(28-87)$ & $40(32-77)$ & & 0.0001 \\
\hline \multicolumn{8}{|l|}{ Gender [n (\%)] } \\
\hline Male & $16(10.5)$ & $19(12.5)$ & $26(17.1)$ & $6(3.9)$ & $6(3.9)$ & $73(48)$ & 0.784 \\
\hline Female & $46(8.2)$ & $55(9.8)$ & $143(25.5)$ & $16(2.9)$ & $1(0.2)$ & $261(46.6)$ & \\
\hline \multicolumn{8}{|l|}{$\begin{array}{ll}\text { Medical history } \\
{[\mathrm{n}(\%)]}\end{array}$} \\
\hline Diabetes & $10(16.1)$ & $11(14.9)$ & $29(17.2)$ & $4(18.2)$ & $1(14.3)$ & & 0.991 \\
\hline $\begin{array}{l}\text { MI or ischemic } \\
\text { Heart disease }\end{array}$ & 1 (1.6) & 0 & $1(0.6)$ & 0 & 0 & & \\
\hline $\begin{array}{l}\text { Chronic heart } \\
\text { failure }\end{array}$ & 0 & 0 & $1(0.6)$ & 0 & 0 & & \\
\hline CVA & $3(4.8)$ & $1(1.4)$ & $8(4.7)$ & $1(4.5)$ & $1(14.3)$ & & 0.484 \\
\hline $\begin{array}{l}\text { Urine protein/ } \\
\text { Creatinine ratio, } \\
\mathrm{mg} / \mathrm{mg} \\
{[\text { median (range) }]}\end{array}$ & $\begin{array}{l}0.59 \\
(0.20-6.49)\end{array}$ & $\begin{array}{l}0.54 \\
(0.21-17.1)\end{array}$ & $\begin{array}{l}0.13 \\
(0.0-6.46)\end{array}$ & $\begin{array}{l}0.68 \\
(0.11-11.76)\end{array}$ & $\begin{array}{l}0.24 \\
(0.01-4.68)\end{array}$ & & 0.0001 \\
\hline \multicolumn{8}{|l|}{ Age $(n)$} \\
\hline $19-29(7)$ & 1 & 0 & 1 & 1 & 0 & $3(42.9)$ & \\
\hline $30-39(43)$ & 2 & 4 & 8 & 3 & 3 & $20(46.5)$ & \\
\hline $40-49$ (126) & 14 & 11 & 21 & 6 & 2 & $54(42.9)$ & $\begin{array}{l}x^{2} \text { for } \\
\text { trend, } \\
p=0.901\end{array}$ \\
\hline $50-59(209)$ & 21 & 22 & 48 & 6 & 0 & $97(46.4)$ & \\
\hline $60-69(171)$ & 17 & 15 & 43 & 5 & 1 & $81(47.4)$ & \\
\hline $70-79(128)$ & 6 & 17 & 39 & 1 & 1 & $64(50)$ & \\
\hline$>80(28)$ & 1 & 5 & 9 & 0 & 0 & $15(53.6)$ & \\
\hline
\end{tabular}

Note: MI, myocardial infarction; CVA, cerebrovascular accident.

\section{DISCUSSION}

We screened 712 patients with known hypertension for CKD. Individuals were invited to enroll for this study, so this was not a random selection of patients with hypertension in Riyadh. In keeping with this, approximately $80 \%$ of the patients studied were female. For these reasons, our findings cannot be generalized to the whole population. With these provisos, our data showed a high prevalence of CKD of $46.9 \%$ (95\% CI: 43.250.7) in outpatients with hypertension in Riyadh. Of particular concern $27.1 \%$ of patients had significant CKD with an eGFR of $<60 \mathrm{~mL} / \mathrm{min}$ (CKD stages 3-5). Hypertension is recognized to be an important cause of chronic renal failure in outpatients as well as in inpatients in Saudi ${ }^{(9,10)}$. In a 6-year study of 3632 patients with end-stage renal disease (ESRD), based on South African Dialysis and Transplant Registry statistics, hypertension was reported to be the cause of ESRD in $4.3 \%$ of whites, $34.6 \%$ of blacks, $20.9 \%$ of mixed ethnic group, and $13.8 \%$ of Indians ${ }^{(17)}$. There are few data on the prevalence of CKD from
Saudi. Sumaili et al. ${ }^{(8)}$ reported a prevalence of proteinuria of $12.4 \%$ in a randomly selected population in the Democratic Republic of Congo. In a "high-risk" population in the same country with diabetes, hypertension, HIV infection, or obesity, the prevalence of CKD was $36 \%{ }^{(18)}$. In Nigeria reported that $10.4 \%$ of patients in a family medical practice had an eGFR $<60 \mathrm{~mL} / \mathrm{min}{ }^{(7)}$. An important observation in our study was that $28.9 \%$ of the patients studied had proteinuria. The degree of proteinuria was higher in CKD 1,2, and 4 than in CKD 3 and 5 and we don't have enough evidences to justify this conclusion. . The causes of the proteinuria were not sought in our study but could be due to hypertensive renal damage, diabetes, or an underlying glomerulonephritis. Patients with diabetes had a significantly higher level of proteinuria compared to patients without diabetes. CKD was also more common in patients with coexistent diabetes at $50.5 \%$, but this did not differ significantly from patients without diabetes at $44.7 \%$. Blood pressure control and 
angiotensin blockade are known to be important in slowing down the progression of kidney failure ${ }^{(19)}$. In our study, blood pressure control was not appropriate with a median blood pressure of 150/90. Furthermore, only $19.6 \%$ of patients without diabetes were treated with angiotensin blockade as compared to $67 \%$ of patients with diabetes. Clearly the benefits of angiotensin blockade in patients with diabetes and proteinuria were better recognized than in patients without diabetes. This is a target for ongoing education for patients and medical and nursing practitioners. CKD is established as a major risk factor for cardiovascular disease ${ }^{(6)}$. In our study, prior myocardial ischemia or heart failure was found in only $0.7 \%$ of patients. This is in keeping with the relatively low rates of myocardial ischemia in Saudi ${ }^{(20)}$. Cerebrovascular accidents were more common and found in $4.2 \%$ of patients. There was no correlation between worsening renal function and cardiovascular disease but the numbers of events were small. This apparent low risk of cardiovascular disease in our patients with CKD is still unexplained, and if confirmed with other studies from Saudi, it would be of interest in view of the higher risk described in other parts of the world ${ }^{(6)}$. In contrast to previous studies, patients with a lower eGFR were significantly younger than patients with a higher eGFR ${ }^{(3)}$. They also had a higher blood pressure. Unlike in other studies, where the prevalence of CKD was higher in females than in males ${ }^{(3)}$, we found the prevalence to be the same. There are several limitations to our findings. First, the serum creatinine measurement was not isotope dilution mass spectrometry traceable and this makes the eGFR calculation using the MDRD equation is inaccurate. Second, CKD assessment was based on single serum creatinine and urine protein measurement. If we followed this conclusion, this would increase the prevalence of CKD. With these provisos, we report a high prevalence of CKD in hypertensive patients in Saudi. Hypertension is common in Saudi and affects approximately $30 \%$ of the adult population ${ }^{(13,14)}$. The high prevalence of CKD found in our study if confirmed could be of great public health concern. The high prevalence of hypertension-related CKD in our study merits comparison with Arabs who shares a common ancestry with Saudis. Arabs has a 3.7 times higher age-adjusted risk of
ESRD ${ }^{(22)}$. As compared with whites, male Arabs with hypertension are 2.1-2.2 and females 2.8-3.6 times more likely to develop end-stage renal failure ${ }^{(23)}$. The recently described association between non-diabetic CKD, focal segmental glomerulo-sclerosis, and hypertensive ESRD in Arabs and the nonmuscle myosin heavy chain type II isoform A (MYH9) gene polymorphisms ${ }^{(24-26)}$ may be of relevance to Saudi with CKD. Some patients with CKD 3 will eventually progress to endstage renal failure. Follow-up of patients in our study will provide useful insight into the clinical course of CKD in Saudi. Our study does, however, suggest the importance of screening for CKD in resource-poor areas as good blood pressure control and treatment with angiotensin blockade slow deterioration of renal function ${ }^{(27,28)}$.

\section{REFERENCES}

1. Chadban SJ, Briganti EM, Kerr PG et al. (2003): Prevalence of kidney damage in Australian adults: The AusDiab kidney study. J Am Soc Nephrol., 14:S131-S138.

2. Chen N, Wang W, Huang $Y$ et al. (2009): Community-based study on CKD subjects and the associated risk factors. Nephrol Dial Transplant., 24:2117-2123.

3. Coresh J, Selvin E, Stevens LA et al. (2007): Prevalence of chronic kidney disease in the United States. J Am Med Assoc., 298:2038-2047.

4. Hallan SI, Coresh J, Astor BC et al. (2006): International comparison of the relationship of chronic kidney disease prevalence and ESRD risk. J Am Soc Nephrol., 17:2275-2284.

5. El Nahas M (2005): The global challenge of chronic kidney disease. Kidney Int., 68:2918-2929.

6. Go AS, Chertow GM, Fan D et al. (2004): Chronic kidney disease and the risks of death, cardiovascular events, and hospitalization. N Engl J Med., 351:1296-1305.

7. Afolabi MO, Abioye-Kuteyi EA, Arogundade FA et al. (2009): Prevalence of chronic kidney disease in a Nigerian family practice population. South African Family Practice, 51:132-137.

8. Sumaili EK, Krzesinski JM, Zinga 
CV et al. (2009): Prevalence of chronic kidney disease in Kinshasa: Results of a pilot study from the Democratic Republic of Congo. Nephrol Dial Transplant., 24:117-122.

9. Plange-Rhule J, Phillips R, Acheampong JW et al. (1999): Hypertension and renal failure in Kumasi, Ghana. J Hum Hypertens., 13:37-40.

10. Lengani A, Laville $M$, Serme $D$ et al. (1994): Renal insufficiency in arterial hypertension in black Africa. Presse Med., 23:788-792.

11. Matekole M, Affram K, Lee SJ et al. (1993): Hypertension and end-stage renal failure in tropical Africa. J Hum Hypertens., 7:443-446.

12. Cooper R, Rotimi C, Ataman S et al. (1997): The prevalence of hypertension in seven populations of west African origin. Am J Public Health, 87:160-168.

13. Amoah AG (2003): Hypertension in Ghana: A cross-sectional community prevalence study in greater Accra. Ethn Dis., 13:310-315.

14. Cappuccio FP, Micah FB, Emmett L et al. (2004): Prevalence, detection, management, and control of hypertension in Ashanti, West Africa. Hypertension, 43:1017-1022.

15. Levey AS, Bosch JP, Lewis JB et al. (1999): A more accurate method to estimate glomerular filtration rate from serum creatinine: A new prediction equation. Modification of Diet in Renal Disease Study Group. Ann Intern Med., 130:461-470.

16. Levey AS, Coresh J, Balk E et al. (2003): National Kidney Foundation practice guidelines for chronic kidney disease: Evaluation, classification, and stratification. Ann Intern Med., 139: 137-147.

17. Naicker $S$ (2003): End-stage renal disease in sub-Saharan and South Africa. Kidney Int Suppl., 63(83):S119-S122.

18. Sumaili EK, Cohen EP, Zinga CV et al. (2009): High prevalence of undiagnosed chronic kidney disease among at-risk population in Kinshasa, the Democratic Republic of Congo.
BMC Nephrol., 10:18.

19. Kidney Disease Outcomes Quality Initiative (2004): K/ DOQI clinical practice guidelines on hypertension and antihypertensive agents in chronic kidney disease. Am J Kidney Dis., 43:S1-S290.

20. Amoah AG, Kallen C (2000): Aetiology of heart failure as seen from a National Cardiac Referral Centre in Africa. Cardiology, 93:11-18.

21. van Deventer HE, George JA, Paiker JE et al. (2008): Estimating glomerular filtration rate in black South Africans by use of the modification of diet in renal disease and Cockcroft-Gault equations. Clin Chem., 54:1197-1202.

22. https://www.ncbi.nlm.nih.gov/pmc/a rticles/PMC4455192/

23. Xue JL, Eggers PW, Agodoa LY et al. (2007): Longitudial study of racial and ethnic differences in developing end-stage renal disease among aged medicare beneficiaries. J Am Soc Nephrol., 18:1299-1306.

24. Freedman BI, Hicks PJ, Bostrom MA et al. (2009): Polymorphisms in the non-muscle myosin heavy chain 9 gene (MYH9) are strongly associated with end-stage renal disease historically attributed to hypertension in African Americans. Kidney Int., 75:736-745.

25. Kao WH, Klag MJ, Meoni LA et al. (2008): MYH9 is associated with nondiabetic end-stage renal disease in African Americans. Nat Genet.,40:1185-1192.

26. Kopp JB, Smith MW, Nelson GW et al. (2008): MYH9 is a major effect risk gene for focal segmental glomerulosclerosis. Nat Genet.,40:1175-1184.

27. Bello AK, Nwankwo E, El Nahas AM (2005): Prevention of chronic kidney disease: A global challenge. Kidney Int Suppl., 68(98): S11-S17.

28. Hoy WE, Baker PR, Kelly AM et al. (2000): Reducing premature death and renal failure in Australian aboriginals. A community- based cardiovascular and renal protective program. Med $\mathbf{J}$ Aust., 172:473-478. 